\title{
INTERACTION OF TRADITIONAL AND CONTEMPORARY MUSIC PEDAGOGY IN THE CASE OF MUSICAL HERITAGE OF NIŠ AND LESKOVAC REGION
}

\author{
UDC [784.9+(371.3:78)]:784.4 (497.11 Niš, Leskovac)
}

\section{Slobodan Kodela, Igor Nikolić}

University of Niš, Faculty of Arts, Serbia

\begin{abstract}
The paper points out the necessity and importance of the study and preservation of traditional local vocal practice that finds its way into contemporary music and teaching. Implementation of traditional songs is an important means by which we solve numerous requirements of teaching music. By its application we raise the students and get them to know the traditional way of life, thinking, transmission and preservation of traditional values and specific examples emerged from musical practice. Here are presented the research of not so many authors, who were engaged in collecting, recording and studying folk singing of southeast Serbia, with a focus on the research of traditional songs of Niš and Leskovac area. Also are shown the recent studies (Pamjav et al. 2012; Brown et al. 2014), dealing with the genetic background of people's attitudes toward traditional music. The paper points out the need to preserve authenticity of traditional songs and their performative characteristics (artists of Niš and Leskovac area) but also the need of their application in modified 'attire', adjusted and applicable in the music teaching. Application of different genres (children's songs, songs of art music, vocal fragments of instrumental music, etc.) in the process of music education significantly affects the formation of musical taste of pupils/students and contributes to the acquisition of knowledge and skills by applying different forms of work. The essence of the research of traditional music with the use of mentioned educational approaches is introduction to and the preservation of our own musical traditions, and confirmation of the national identity.
\end{abstract}

Key words: music pedagogy, traditional singing, solfeggio, textbooks

Received October 6, 2016 / Accepted November 1, 2016

Corresponding author: Slobodan Kodela

University of Niš, Faculty of Arts, Niš, Republic of Serbia

E-mail: kboban64@gmail.com 
Preservation of concrete examples of traditional musical practice of what represents sustainability of musical heritage, certainly is the important tasks not only of the social environment in which the traditional is created, but also contemporary music education, which through its pedagogical and methodological way indicates the need for the application of (concrete) examples of Serbian traditional performance. From the aspect of music pedagogy i.e. its pedagogical practice, introducing examples of traditional songs to the music classes represents a need and objective. With its implementation we solve a number of tasks of teaching music, students get to know the traditional way of life, thinking and transferring traditional values. This is certainly important, because we believe that as educators we have a mission to encourage students and refer to preserve traditional values.

Implementation of traditional vocal performance in the process of music education (which includes the teaching of music in general education and teaching solfeggio in schools with professional orientation), is the object of study primarily of music educators and methodologists, but also ethnomusicologists and psychologists of music, who in different areas and through various forms of work try to set Serbian vocal tradition as the basis of learning music. This is particularly evident in the early stages of musical literacy, but also important for the entire period of musical education. In this sense Serbian vocal tradition is the inexhaustible source of study and application of folk songs in music teaching practice.

"Traditional native songs are musical language of a specific environment ${ }^{1} \ldots$ and knowing them must be used in order to facilitate learning musical notation, mastering and subsequent permanent adoption of functionality of tonal relations, as is the case of teaching mother tongue language" (Drobni 2008, 97). In this regard, the success of teaching music is conditioned by the kind of system that we use for music education, which is based on " ... the respect and preservation of tradition and established values ... with sublimation of traditional influence with the needs of music education directed toward the European mainstream ..." (Drobni 2008, 132).

Historically, the study of Serbian traditional music, hence the traditional songs, were not numerous. In the middle of the nineteenth century we find the first printed collection of folk songs and in early twentieth century comes to the formation of ethnomusicological science. ${ }^{2}$

When we talk about the collecting, recording and study of traditional folk singing of southeast Serbia, in particular the traditional folk songs of Niš and Leskovac area, we can conclude that these studies have been scarce. ${ }^{3}$ Among the first researchers who have studied on the above-mentioned area and collected folklore and ethnographic content, thus the traditional songs, we can mention Vladimir Petrović (1900). The first records of

\footnotetext{
${ }^{1}$ This construction relates to a melody component of songs.

${ }^{2}$ In her book Serbian folk music, Radmila Petrović points out that the study of folk music in Serbia covers the last hundred years and recognizes in them the development phases "... which have their special characteristics, forming a path from the Serbian musical ethnography to Serbian ethnomusicology" (Petrović 1989, 3).

${ }^{3}$ In addition to the above mentioned ascertainment we introduce the results of field research, which was conducted in 2004 , and where the author points to the "disappearance of collective practice (ensembles of any kind, even polyphonic singing), as well as the disappearance of instrumental practice ... From this we can conclude that some elements of the traditional heritage of Niš (though this phenomenon is not only related only to this area) will inevitably be handed over to oblivion, as it were, for example, some songs recorded in a unanimous performance, although the singers stressed that the the performance that they remember was that of many voices" (Hofman \& Marković 2005, 12).
} 
lazaričke and kraljičke songs from Leskovac region were recorded at the beginning of the XX century in Niš's Journal Kića which was published in the period from 1905 to 1913. Great importance in the study of oro tradition but also in collecting folk songs of Niš region in the period between the two world wars had sisters Ljubica and Danica Janković $(1952,39-40,52-62)$. Contribution to the study of musical tradition from this region, its collecting and recording gave Vladimir Đorđević (1931), Kosta Manojlović (1953), Miodrag Vasiljević (1960) and Ana Hofman (2005). ${ }^{4}$ The works of those authors present a significant contribution to the Serbian ethnomusicology, as well as the study of Serbian vocal tradition of Niš and Leskovac region in a wider context.

However, traditional singing of Niš and Leskovac area today as a phenomenon has almost entirely disappeared from everyday musical practice, and with it the transference of sung musical material by oral tradition, as well as by regular social practice. What we today sporadically encounter is certainly different from the function of ritual-traditional genres that was evident and recognizable in the ritual practice of Niš and Leskovac area, composed centuries ago.

We would point out, as a special problem, the lack of musical material and traditional songs which today can be recorded and preserved. ${ }^{5}$ Today there are a large number of villages in which traditional singing does not exist for a long time, the traditional song was not sung for a long time because there is no one to perform it, and we will probably never have the opportunity to find out how the traditional singing once looked like. The reason is that we have not sufficiently preserved the traditional singing on time. Certainly that the general social development, ideology, urbanization, ruralisation, changes in lifestyle, significantly influenced the transfer, and thus the preservation of musical tradition. As a "result" we find the fact that today it lost its implementation and its original function.

Serbian vocal tradition (as stated) in its evolutionary development has experienced diverse and numerous changes (mainly aesthetic). This is primarily related to new functions that have coresponded to different times and circumstances in which the practice of singing developed (Kodela \& Todorović 2014, 505). In Serbian traditional singing and its practice, there is a visible continuity in the development, through various forms of folk vocal expression: from ritual (recognizable by the "rules" of the ritual, i.e. ritual actions, and songs that formed an integral part), to the lyrical. Significant transformations of Serbian ritual singing (referring to the Niš and Jablanic region), viewed over time, followed along with

\footnotetext{
${ }^{4}$ In addition to the named authors and works, certainly is a need to mention among them the work of Dragoslav Dević referring to the region Svrljig - Svrljig Cultural History, Language, Culture and Civilization (Kulturna istorija Svrljiga, jezik, kultura i civilizacija, Prosveta Niš, Narodni univerzitet Svrljig, Narodna muzika 427539), the work of Zlata Marjanović-Krstić Vocal music tradition of village Brza (Vokalna muzička tradicija sela Brza) and graduate students' theses of the Department of Ethnomusicology at the Faculty of music in Belgrade, who dealt with the traditional characteristics of musical practice of Niš and Leskovac area.

${ }^{5}$ The views on the importance of preserving tradition, and within that traditional music, we find in the article (Rzeszutek et al. 2012) which is based on the study of archival recordings of traditional songs ( $\mathrm{N}=421$ ) of different populations in Taiwan and the Philippines, comparing their similarities and differences. The authors emphasize that the archival recordings are "essential in a world where globalization and the associated expansion of Western culture threaten to extinguish much of the rich cultural diversity", as important characteristics of populations around the world. In fact, there is no doubt that the indigenous traditional music of many nations have already taken on elements of Western culture in the process that the authors of this study called a kind of "imposed hybridization" (Rzeszutek et al. 2012). In this sense, archival recordings of traditional music (i.e. the effort to preserve the musical values that in the future we will certainly not find in their original form) represent not only a contribution to the preservation of culture and tradition, but also a valuable material for future scientific research.
} 
larger social changes brought by the modern notion of musical culture (Kodela \& Todorović 2014, 505). In the initial stage of its development, typical was the existence of a song within the syncretism with many elements of acting, music and dance. This lasted until the moment when desacralization began, which is based on changing the consciousness and the relationship of man to the belief in the real and unreal world. Basically remains their archaic origin and meaning appropriate function. However, the correlation of “... the music and the broader social practice allows us, not only through the folk and traditional music, to look at the way a society is functioning and comprehending reality, because the traditional music is a mediator that connects the previous and the next generation by passing it on from parents to children's cultural heritage and upbringing ..." (Stojanović 2009, 7).

The study of traditional vocal expression and traditional songs can be viewed from the pedagogical, aesthetic, psychological and genetic aspects. Although in the scientific literature we found the least data on the impact of genetic factors on the process of understanding, memorising and transmission of traditional music, it is important to emphasize the assumption of the existence of "genetic code", thanks to which a certain type of music is "more suitable" and "understandable" to one nation. The development of genetics as a science has enabled the empirical verification of this thesis.

One research that systematically studies the genetic background of people's attitudes toward traditional music (Pamjav et al. 2012) included thirty-one nation in Europe and Asia, including Serbia. The objective of the research was to compare features of traditional music with the genetic specificities of the covered population, through statistical analysis of various aspects of traditional songs. The authors have developed a computer system that primarily takes into account the contour of the melody, while also is analyzed rhythmic aspect of music. General results of this study indicated a statistically significant $82 \%$ probability that nations with similar musical cultures have a similar genetic structure, suggesting as a conclusion the connection between traditional music and genes. Another important information derived from this study shows that maternal lines have a larger role than paternal in transmission of the musical genetic material.

Other relevant research (Brown et al. 2014) studied the connection between genes, language and traditional music among the nine indigenous population in Taiwan. The results show a statistically significant correlation between genes and music $(r=0.417$, $\mathrm{p}=0.015)$ as well as genes and language $(\mathrm{r}=0.492, \mathrm{p}=0.006)$, while it is the interesting fact that the correlation of music and language in this study is not statistically proven. Including other factors in the analysis, Brown and colleagues came to the conclusion that music in relation to the language is closer to the genes, which probably reflected on the "mechanisms of evolution, migration and cross-cultural contacts" (Brown et al. 2014, 5). This has supported the claim that the music and the genes have evolved together over time. Thanks to the results, Brown and his cooperators give to traditional music another important function (supported by other authors, for example Jobling, 2014) - the function of "marker", which (in addition to genes and language) can contribute to the study of historical migrations of different nations.

Despite the above mentioned evidence of the existence of musical "genetic code", knowledge and understanding of traditional music cannot be explained only by inheritance. It is undeniable that early, informal musical experiences have a huge impact on musical taste as well as the course and outcome of subsequent musical education. For 
this reason, we must turn to pedagogy as one of the possible ways to preserve traditional music. It would be, on the other hand, accelerated by "appropriate" kind of music, that is, convenient genetic material which originated in a specific geographical area, in our case, Niš and Leskovac area.

On this occasion we will present observations and interpretations that have arisen as a result of the research of traditional music, specifically ethnomusicological "field" practice, which relates to the consideration of the phenomenon: how and in what manner did the excellent singers reach the perfect performing level of traditional performance (singing) and whether it is conditioned by kind of folk pedagogic - educational principles?

In his book Is there a folk music pedagogy, ${ }^{6} \mathrm{D}$. Golemovic points out that "regular practice" of Lazarica ritual includes arrival of the girls participants to male and female Lazar, to learn (a kind of "pedagogical" engagement) songs and rituals from the older singers (mostly women as carriers of singing-ritual practice). It would benefit the ritual, respecting and imitating "traditional" way of performing, which is learned and accepted many generations ago, and were created on the "spot", i.e. at a certain moment of the performance of the song. ${ }^{7}$ Even in Kraljički ritual we meet specific "guidelines" which are of benefit to performers (participants) of the ritual, in the actions that suggest what and how to do in any part of the ceremony. We recognize them mostly in the chorus of song. ${ }^{8}$ So "their musical material and the manner of performance, as it is traditionally taught, women (added S. K.) passed on to the younger generation" (Petrović 1989, 88).

In the Serbian patriarchal family first musical skills and musical insight, as well as the first "songs" and dances, children have gained from theirs grandmothers because they spent with them most of the time, since the mothers were occupied by works in the field. In this way, children acquired first musical and linguistic experiences. "During the childhood from the 'consumer' of the mentioned songs/dances, the child has become their performer, and even their creator ..." (Golemović 2006, 164). An interesting phenomenon is the use of the terms by ritual singers, usually before performing the ritual, with the aim of emphasizing or highlighting instructions for performing songs of ritual-conventional genres. Different terms (singing na glas, in two voices - na bas, the women who leads the diphthong zanosi, izvrta, the woman accompanying the leading voice dube, zvuče, voze; kratak glas indicates the syllabic singing, in relation to a dugačak glas, etc.) are "linguistic determinants of musical expression among Serbs and explain many elements of

\footnotetext{
${ }^{6}$ Author of the book uses pedagogy in terms of skill of education, and not in the context of education science (Golemović 2006, 163).

${ }^{7}$ Miodrag Vasiljević as well in describing Lazarica ritual makes a distinction between Lazaricas that are musically or poetically most gifted and those participating in the ritual that are not: ,The first couple of singers ... the ones that began the verse (in the vicinity of Niš, Vranje and Leskovac), i.e. those that lead in singing and that lead the singing part of the ritual ... She is most gifted poetically and musically because she often had, at the request of the host, or any member of the family in front of whose house ritual was performed, a task to improvise some new text, and even a new tune ... The other two singers, krošnjarke, were repeating the verse that they heard" (Vasiljević 1960, 31).

${ }^{8}$ For example, in the chorus of the song the word $d o z$ would mean a movement in the dance in which artists approach completely (as opposed to, or next to each other), when it comes to the Kraljica ceremony, ljeljo or lado, would imply a type instruction to the performers of the ritual to swing or shake during the dance. The term lado, "according to its old Slavic meaning - harmony or order, could be referring to as a 'command' to dancers to take such a position“ (Radenković 1999, 130).
} 
its musical understanding, expression and musical performance ..." (Petrović 1989, 63). Given the above, we can conclude that the answer to the question whether there is a folk music pedagogy is undoubtedly yes "with the necessary notice which states that folk and school pedagogy are not the same, but there is also the question why would they be, when the musical practices that are related to them are not the same either" (Golemovic 2006, 62).

When it comes to the role of song in schools, especially in schools with a professional music orientation, we agree with the statement that "... every musical impression, i.e. beautiful melody ... in its own way contributes to the development of hearing, awareness of tones and deposition of sound pictures on one hand, and on the other hand encourages students to whenever they receive sound impressions, listening and deliberate or spontaneous memorizing, try to consciously define the sound, follow the continuity and identify elements that are adopted in teaching" (Pantović \& Kršić-Sekulić 1996, 1). The task of teaching solfeggio in the initial music education is focused on the acquisition of fund of sound notions, which is created through the process of education and serves as a "base" for acquisition of (sound) associations. Association remain stored in the mind, and they can be "run" by a specific visual stimuli. "When it ... comes to the level where the understanding of the music content can provide the performance, the circle is complete and perfect. This means that at a certain level of teaching was established a flow of musical thought. The process of sighting-understanding-reproduction ${ }^{9}$ constantly circulates and renews itself" (Todorović \& Kodela 2014, 646).

We can reasonably ask whether traditional/folk songs (melodies) can be introduced into the teaching process, taking into account the need to preserve the originality and authenticity of the song. ${ }^{10}$ One should keep in mind the characteristics of ritual singing practice (nasality, guttural singing, singing with the stronger intensity of voice, singing with "clenched" throat - characteristics of ritual singing practice of Leskovac area, etc.). Surely that ".... songs that were collected in the field, and that we introduce, that is, apply to the music teaching, are sang in the way the folk singers do, but with respect to (i.e. with a 'supplement') and insisting on precise and ... (clear) diction during the performance, articulation, phrasing, tempo, agogics, dynamics, all in the aim of musical, beautiful singing. In this way, we do not essentially change the ritual singing, but we enrich it and introduce it to the classes into something different 'attire' (Kodela \& Todorović 2014, 507).

We should bear in mind the possibilities for a different approach, treatment and implementation of traditional/folk musical creative work in this area, especially when it comes to the textbook literature in schools with professional orientation (primarily for the subject Solfeggio). ${ }^{11}$ In the most commonly used textbooks with us (for elementary music school) by Borivoje Popović and Vladimir Jovanović, we do not find examples of traditional/folk, art and children's songs. A somewhat different approach to the content are found in textbooks that are designed for the lessons of the rhythm, by Zorislava M. Vasiljević and Tatjana Drobni - Solfeggio-rhythm from I to VI class. In the preface to the first book the authors suggest the following "... tutorial to learn the rhythm in which it ranged from folk and other songs to the image and interpretation of rhythm, not just arid exercises printed on one line, or more arid music theory" (Vasiljević \& Drobni 1999). We

\footnotetext{
${ }^{9}$ A maxim of Zorislava Vasiljević.

${ }^{10}$ On the use of folk songs and dances in their original, authentic form, see in: Karan 2006.

${ }^{11}$ More detailed in the work: Kodela, 2012.
} 
would like to mention the textbooks for the subject Solfeggio of a group of authors (V. Cvetković, J. Mihaljica, A. Jović Miletić, Z. Nikolić, G. Stojanović), which in addition to instructive examples, examples of vocal and instumental literature, introduce the examples of Serbian folk/traditional songs. It is interesting to mention that in these textbooks (six in total, one for each class of six-year education), we find four songs of Niš and Leskovac area (in the textbook for the fifth grade) - or, more precisely - three folk songs from the (vicinity of) Leskovac and one song from the city of Niš. Based on these findings, we can conclude that pupils of primary music schools in Serbia may be introduced with traditional musical heritage of Niš and Leskovac area (which is of particular relevance to students who were born in this region) only through the aforementioned textbook. They can get elementary information on their vocal tradition, their musical legacy, the one they definitely "bear in themselves", and that for centuries was created on this area, provided that the solfeggio teacher singled out this tutorial for teaching!

\section{INSTEAD OF CONCLUSION}

The fact is that nurturing traditional expression, the one that is authentic, original, from the aspect of national creativity and traditional performance, is now reduced to performing in folklore ensembles, different folklore orchestras or sporadically in schools. It loses, or more precisely, it has lost its authentic thread, its indigenous (original) form. The aforementioned methods of nurturing and performing traditional creativity are aimed that the pupils/students introduce with the lifestyle and traditional thinking, which in return directly affects the process of transferring and preserving traditional values by specific examples of musical practice. Seemingly, it is for us the return to a long gone time, in a past. But no, it is returning to our own recognition, it is a confirmation of our own identity, which in fact is the essence of the research of traditional music.

The complexity of the music and the teaching process involves knowing and studying different genres: children's songs, examples from the art literature, the introduction of new modern trends in popular music and the like, in order to thus influence the formation of musical taste. The application of traditional/folk songs in the music teaching would not have for a goal an aspire to "folklore universality, perfectionism" or "perfection" in the knowledge of (Niš and Leskovac) folk singing in terms of performance, but the knowledge and diversity of performing flexible (precisely selected) musical content of various genres designed for music education. Because, if we educate pupils/students to be connoisseurs of folk creativity of their region or traditional creativity of other parts of Serbia and abroad, it would not mind to focus their desires, knowledge, and skills on the art music of domestic and foreign composers, the genre diversity, its knowledge and performance. 


\section{REFERENCES}

Brown, S., P. Savage, A. Min-Shan Ko, M. Stoneking, YC. Ko, JH. Loo \& J. Trejaut. (2014). Correlations in the population structure of music, genes and language. Proc. R. Soc. B, 281: 20132072. [Online]. Available: http://dx.doi.org/10.1098/ rspb.2013.2072

Drobni, I. (2008). Metodičke osnove vokalno-instrumentalne nastave. Beograd: ZUNS

Đorđević, V. (1931). Srpske narodne melodije, (predratna Srbija), knj. II. Beograd: Izdavačka knjižarnica Gece Kona

Golemović, D. (2006). Čovek kao muzičko biće - Da li postoji narodna muzička pedagogija? Beograd: Biblioteka $\mathrm{XX}$ vek

Golemović, D. (s.a). I kad se popneš na vrh drveta, ne zaboravi na njegov koren / Tradicionalna narodna muzika u nastavi muzičke umetnosti, manuscript.

Hofman, A. \& A. Marković. (2005). Vokalna muzička tradicija okoline Niša. Beograd, Niš: Centar za istaživanje muzike Balkana, Punta

Janković, Lj. \& D. Janković. (1952). Narodne igre, knj. VII, Beograd: Prosveta

Jobling, M. (2014). The music of the genes. Investigative Genetics, 5/2. [Online]. Available: http://www.investigativegenetics.com/content/5/1/2

Karan, G. (2006). Igra u funkciji tumacenja muzike deci najmladjeg uzrasta / Narodna pesma i igra u funkciji tumacenja dvodela. In V. Milanković (Ed.), Zbornik radova Osmog pedagoskog foruma. Beograd: Fakultet muzičke umetnosti, 97-119.

Kodela, S. (2012). Tradicionalna pesma u udžbeničkoj literaturi nastave solfeđa u osnovnim muzičkom školama. In S. Marinković, S. Dodik (Eds.), Vlado S. Milošević: etnomuzikolog, kompozitor i pedagog, zbornik radova. Banja Luka: Akademija umjetnosti, Muzikološko društvo Republike Srpske, 101-107.

Kodela, S. \& D. Todorović, D. (2014). Srpski muzički identitet - kontinuirani spoj tradicije i savremenosti, Tradicionalni muzički izraz u nastavi muzike. In B. Dimitrijević (Ed.), Savremene paradigme u nauci $i$ naučnoj fantastici. Niš: Filozofski fakultet

Manojlović, K. (1953). Narodne melodije iz istočne Srbije, knj. CCXII, knj. 6. Beograd: SANU, Muzikološki institut

Pantović, Lj. \& V. Kršić-Sekulić. (1996). Funkcionalnost intervala i akorada. Beograd: Marcompany

Pamjav, H. Z. Juhász, A. Zalán, E. Németh \& B. Damdin. (2012). A comparative phylogenetic study of genetics and folk music. Molecular Genetics and Genomics, 287/4, 337-349.

Petrović, V. (1900). Zaplanje ili Leskovačko (u Srbiji). In A. Radić (Ed.), Zbornik za narodni život i običaje Južnih Slovena, sv. V. Zagreb, 280-283.

Petrović, R. (1989). Srpska narodna muzika - Pesma kao izraz narodnog muzičkog mišljenja. Beograd: SANU, Muzikološki institut

Radenković, LJ. (1999). Pripevi lado i ljeljo u narodnim pesmama istočne i južne Srbije. Etno-kulturološki zbornik, $V$. Svrljig: Etno-kulturološka radionica, 130.

Rzeszutek, T, P. Savage \& S. Brown. (2012): The structure of cross-cultural musical diversity. Proceedings of the Royal Society B: Biological Sciences, 279 (1733), 1606-1612. doi:10.1098/rspb.2011.1750

Stojanović, D. (2009). Mogućnosti i potencijali dijaloga etnomuzikologije i teorije roda. Beograd: Fakultet muzičke umetnosti, Katedra za etnomuzikologiju, MA Thesis

Todorović, D. \& S. Kodela. (2014). Sinergija opažanja, reprodukcije i muzičkog mišljenja u nastavi solfeđa. In S. Marinković, S. Dodik, A. Petrov (Eds.), Vlado S. Milošević: etnomuzikolog, kompozitor i pedagog, zbornik radova Banja Luka: Akademija umjetnosti, Muzikološko društvo Republike Srpske, 643-648.

Vasiljević, Z. (Ed.). (1996). Srpsko muzičko blago. Cvetnik srpskih narodnih pesama. Beograd: IP Prosveta

Vasiljević, Z. \& T. Drobni. (1999). Solfeđo - ritam. Beograd: FIN \& EK

Vasiljević, M. (1960). Narodne melodije leskovačkog kraja, knj. CCCXXX, knj. 11. Beograd: SANU, Muzikološki institut

Vujaklija, M. (1970). Leksikon stranih reči i izraza. Beograd: Prosveta 


\section{INTERAKCIJA TRADICIONALNE I SAVREMENE MUZIČKE PEDAGOGIJE NA PRIMERU MUZIČKOG NASLEĐA NIŠKOG I LESKOVAČKOG KRAJA}

U radu se polazi od potrebe i značaja za proučavanjem i očuvanjem tradicionalne lokalne vokalne prakse koja svoju primenu nalazi i u savremenoj muzičkoj nastavi. Implementacija tradicionalne pesme predstavlja značajno sredstvo kojim rešavamo brojne zahteve muzičke nastave. NJenom primenom učenike odgajamo i upoznajemo sa načinom tradicionalnog življenja, mišljenja, prenošenja $i$ očuvanja tradicionalnih vrednosti $i$ to konkretnim primerima nastalim iz muzičke prakse. Prestavljena su istraživanja, ne tako brojnih autora, koji su se bavili prikupljanjem, beleženjem i proučavanjem narodnog pevanja jugiistočne Srbije, sa fokusom na istraživanja tradicionalne pesme niškog i leskovačkog kraja. Prikazana su i novija proučavanja (Pamjav et al., 2012; Brown et al., 2014), koja se bave genetskom pozadinom odnosa ljudi prema tradicionalnoj muzici. U radu se ukazuje na potrebu očuvanja autentočnisti tradicionalnih pesama i njihovih izvođačkih karakteristika (izvođača niškog i leskovačkog kraja) ali i na nophodnost primene istih $u$ nešto modifikovanom ruhu, preilagođenom i primenjljivom $u$ muzičkoj nastavi. Primena različitih žanrova (dečije pesme, pesme umetničke muzike, fragmnenti vokalno istrumentalne muzike $i$ sl.) u okviru procesa muzičke edukacije u znatnoj meri utiče na formiranje muzičkog ukusa učenika/studenata $i$ doprinosi sticanju znanja $i$ veština primenom različitih oblika rada. Suština istraživanja tradicionalne muzike uz primenu navedenih edukativnih pristupa ogleda se u upoznavanju i očuvanju vlastite muzičke tradicije i potvrdi nacionalnog identiteta.

Ključne reči: muzička pedagogija, tradicionalno pevanje, solfeđo, udžbenička literatura 